\title{
Prevalence and Risk Factors of Taeniasis In Bali, Indonesia
}

\author{
N W Winianti ${ }^{1 *}$, A A A L Paramasatiari ${ }^{2}$, P Sutisna ${ }^{1}$, D P Widjana ${ }^{1}$, I N W Kapti ${ }^{1}$ \\ ${ }^{1}$ Department of Parasitology, Faculty of Medicine and Health Science, Warmadewa University, Bali, \\ Indonesia \\ ${ }^{2}$ Department of Microbiology, Faculty of Medicine and Health Science, Warmadewa University, Bali, \\ Indonesia \\ *winiantiniwayan84@gmail.com
}

\begin{abstract}
Taeniasis is a neglected infectious disease caused by eating raw or undercooked beef/ pork (Taenia sp.) containing infective cysticercus larvae. Humans can become infected with these tapeworms by eating raw or undercooked beef (T. saginata) or pork (T. solium and T. asiatica). In rural areas of Gianyar including Guwang village, pork or beef "lawar" and roasted pig are consumed as local traditional food since long time ago as part of indegenous Balinese culture. The existence of individual slaughtering of pigs in Guwang village for ceremonies or parties without supervision from the animal health department is thought to increase the risk of taeniasis. Purpose of the study was to known prevalence of taeniasis in Banjar Buluh, Guwang Village and determine risk factors or the relationship between meat consumption and individual characteristics with taeniasis. Observational cross sectional study was used to identify taeniasis and risk factors in people living at Buluh, Guwang village consisted of 110 people. Two subjects from the group were positive for taenia egg both by direct smear methods. Proportion of taeniasis in the case group was $1.8 \%$. The type of meat consumed, methods of meat processing, frequency of consumption, ways of obtaining meat and individual characteristics which may contribute to Taenia infection could not be evaluated due to limited number of positive cases.
\end{abstract}

Keywords: Taeniasis, Direct Smear Method, Taenia $s p$.

\section{Introduction}

Taeniasis is an infectious disease caused by the Taenia sp. Humans can become infected with these tapeworms by eating raw or undercooked beef (T. saginata) or pork (T. solium and T. asiatica) containing infective cysticercus larvae[1]. Taeniasis and cysticercosis is are still prevalent in four provinces in Indonesia namely Papua, Bali, East Nusa Tenggara and North Sumatra[2]. The highest incidence of taeniasis in Bali is found in 4 regency : Gianyar, Karangasem, Badung, and Denpasar[3,4,5]. The highest incidence of taeniasis saginata was in Gianyar Regency and taeniasis solium in Karangasem Regency[6,7].

In rural areas of Sukawati including Guwang village, beef and pork"lawar"and roasted pig are consumed as local traditional food since long time ago as part of indegenous Balinese culture[8]. In survey of Puskesmas 1 Sukawati (Public Health Center) in 2016, 3 positive taeniasis cases found of 12 study subjects in Guwang Village[7]. This result was only survey from people who want for check of their stools. Purpose of the study was to known prevalence of taeniasis in Banjar Buluh, Guwang Village and determine risk factors or the relationship between meat consumption and individual characteristics with taeniasis. 


\section{Method}

Observasional cross sectional study with purposive random sampling was applied in this study. This study was done in May-July 2017. Samples were selected according to the inclusion and exclusion criteria. Inclusion criteria (people at Guwang village) : people consumed meat beef or pork, no previous treatment for taeniasis at least 6 months before the study, The exclusion criteria included children under 1 year old. About 30 grams of fecal samples was collected, $10 \%$ formalin was used for preservative. Normal saline was used for direct method. Light microscope and optilab were used to identify the taenia egg. Risk factors of taeniasis were identified using questionaire. Descriptive analysis was used to explain risk factors (the meat consumption and individual characteristics) which contribute to occurance of taeniasis.

\section{Results And Discussion}

Table 1. Taeniasis in Banjar Buluh, Guwang Village

\begin{tabular}{ccc}
\hline Fecal Sample & Number & Percentage \\
\hline Positive & 2 & 1.8 \\
Negative & 108 & 98.2 \\
Total & 110 & 100.0 \\
\hline
\end{tabular}

Table 1 shows prevalence of taeniasis in Banjar Buluh, Guwang Village, two subjects $(1.8 \%)$ were positive for taenia egg both by direct smear methods

Table 2. Individual Characteristics Taeniasis egg positive subjects in Banjar Buluh, Guwang Village

\begin{tabular}{|c|c|c|c|c|}
\hline \multirow{2}{*}{ Individual Characteristics } & \multicolumn{2}{|c|}{ Positive } & \multicolumn{2}{|c|}{ Negative } \\
\hline & $\mathbf{n}$ & $\%$ & $\mathbf{N}$ & $\%$ \\
\hline \multicolumn{5}{|l|}{ 1. Gender } \\
\hline a. Male & 1 & 0.9 & 54 & 49.1 \\
\hline b. Female & 1 & 0.9 & 54 & 49.1 \\
\hline Total & 2 & 1.8 & 108 & 98.2 \\
\hline \multicolumn{5}{|l|}{ 2. Age (Years) } \\
\hline a. $1-10$ & 0 & 0.0 & 2 & 1.8 \\
\hline b. $11-20$ & 0 & 0.0 & 27 & 24.6 \\
\hline c. -30 & 0 & 0.0 & 20 & 18.2 \\
\hline d. $31-40$ & 2 & 1.8 & 34 & 30.9 \\
\hline e. $41-50$ & 0 & 0.0 & 15 & 13.6 \\
\hline f. $51-60$ & 0 & 0.0 & 10 & 9.1 \\
\hline g. $>60$ & 0 & 0.0 & 0 & 0.0 \\
\hline Total & 2 & 1.8 & 108 & 98.2 \\
\hline \multicolumn{5}{|l|}{ 3. Education level } \\
\hline a. No school & 0 & 0.0 & 0 & 0.0 \\
\hline b. Elementary school & 1 & 0.9 & 12 & 10.9 \\
\hline c. Junior High School & 0 & 0.0 & 15 & 13.6 \\
\hline d. Senior High School & 1 & 0.9 & 54 & 49.1 \\
\hline e. Graduate/ Postgraduate & 0 & 0.0 & 27 & 24.6 \\
\hline Total & 2 & 1.8 & 108 & 98.2 \\
\hline
\end{tabular}




\begin{tabular}{llcccc}
\hline \multirow{2}{*}{ Individual Characteristics } & \multicolumn{2}{c}{ Positive } & \multicolumn{2}{c}{ Negative } \\
\cline { 2 - 5 } & $\mathbf{n}$ & $\mathbf{\%}$ & $\mathbf{N}$ & $\mathbf{\%}$ \\
\hline 4. Occupation & & & & \\
a. No job & 1 & 0.9 & 9 & 8.2 \\
b. Farmer & 0 & 0.0 & 10 & 9.1 \\
c. Business & 0 & 0.0 & 12 & 10.9 \\
d. Village staff & 0 & 0.0 & 10 & 9.1 \\
e. Civil Servant & 0 & 0.0 & 17 & 15.4 \\
f. Seller & 1 & 0.9 & 40 & 36.4 \\
g. Student & 0 & 0.0 & 10 & 9.1 \\
\hline & Total & 2 & 1.8 & 108 & 98.2 \\
\hline
\end{tabular}

Table 2 shows prevalence of taeniasis (egg Taenia sp.was positive) as much as in male and female (male $50 \%$, female $50 \%$, age both $31-40$ years old, the education level elementary school and senior high school and the occupation of subject seller and no job)

Table 3. Characteristics of meat consumption among Taenia egg positive subjects in Banjar Buluh, Guwang Village

\begin{tabular}{|c|c|c|c|c|}
\hline \multirow{2}{*}{ Risk factors } & \multicolumn{2}{|c|}{ Positive } & \multicolumn{2}{|c|}{ Negative } \\
\hline & $\mathbf{n}$ & $\%$ & $\mathbf{n}$ & $\%$ \\
\hline \multicolumn{5}{|l|}{ 1. Meat } \\
\hline a. Pork & 0 & 0.0 & 0 & 0.0 \\
\hline b. Beef & 0 & 0.0 & 0 & 0.0 \\
\hline c. Pork and Beef & 2 & 1.8 & 108 & 98.2 \\
\hline Total & 2 & 1.8 & 108 & 98.2 \\
\hline \multicolumn{5}{|l|}{ 2. Cooking Methods } \\
\hline a. Raw & 0 & 0.0 & 0 & 0.0 \\
\hline b. Undercooked & 2 & 1.8 & 108 & 98.2 \\
\hline c. Cooked & 0 & 0.0 & 0.0 & 0.0 \\
\hline Total & 2 & 1.8 & 108 & 98.2 \\
\hline \multicolumn{5}{|l|}{$\begin{array}{l}\text { 3. Frequency raw or } \\
\text { undercooked meat } \\
\text { (times/week) }\end{array}$} \\
\hline a. No consumption & 0 & 0.0 & 0 & 0.0 \\
\hline b. $>1$ & 2 & 1.8 & 108 & 98.2 \\
\hline Total & 2 & 1.8 & 108 & 98.2 \\
\hline $\begin{array}{l}\text { 4. Methods of obtaining } \\
\text { meat }\end{array}$ & & & & \\
\hline a. Personal slaughtering & 0 & 0.0 & 0 & 0.0 \\
\hline $\begin{array}{ll}\text { b. } & \text { Market } \\
\text { Slaughterhouse } & \text { or } \\
\end{array}$ & 2 & 1.8 & 108 & 98.2 \\
\hline Total & 2 & 1.8 & 108 & 98.2 \\
\hline
\end{tabular}

The relationship between meat consumption (the type of meat consumed, meat processing methods, frequency of consumption, how to obtain meat) with taeniasis both positive subject meat consumption beef and pork, undercooked meat processing methods, frequency of consumption $1 \mathrm{x} /$ week and obtain to meat from market/slaughterhouse.

Taeniasis in this study was found in people in Banjar Buluh, Guwang village, 2 positive taeniasis cases found of 110 study subjects. This is one of the study's weaknesses or limitations. This result was influenced by the willingness of the study subjects to collect stool, 
the time factor, and the respondents' local customs and belief, and the fact of taking the fecal samples to a distant laboratory for examination $[10,11,12]$. In this study the methods used for fecal examination were only direct method with Lugol. It is difficult to distinguish between $\mathrm{T}$. solium / $\mathrm{T}$. saginata / $\mathrm{T}$. asiatica[13]. The two subjects with positive taenia eggs microscopically did not present proglottid so could not determine whether the cases were of taeniasis solium or taeniasis saginata or taeniasis asiatica. Both taeniasis positive samples showed that the direct method with Lugol still good used for fecal examination[2].

Local people's habit of eating food with undercooked pork or beef cannot be removed because it is hereditary and closely related to traditional and ritual ceremonies[14]. Balinese Hindu people including those in Banjar Buluh, Guwang village not only eat pork but also beef. A great segment of Hindu Balinese do eat beef, but according to the religion beef is not allowed for offerings and during religious events[13]. This fact is similar to that in the population of the village Ketewel, Gianyar, who predominantly consume beef lawar. It is clear that people's habit is difficult to change but if the pork or beef consumed is closely observed for cysticercus larvae and meat processing was done properly, then taeniasis cases can be minimized and the transmission source of cysticercosis can also be reduced in the community[13,14,15].

\section{Conclusions}

Proportion of taeniasis among the people in Buluh, Guwang Village was $1.8 \%$. The type of meat consumed, meat processing methods, frequency of consumption, ways of obtaining meat and individual characteristics which may contribute to the taeniasis infection could not be evaluated due to limited number of positive cases.

\section{References}

[1] Centers for Disease Control. Taeniasis. Atlanta: Centers for Disease Control, 2015.

[2] Markell E. Markell and Voge's : Medical Parasitology, edited by John, David T and Petri Jr, William A. Philadelphia : Saunders, 2010

[3] World Health Organization. Taeniasis. Geneva : World Health Organization, 2013

[4] Wandra T, Margono SS, Gafar. Taeniasis/cysticercosis di Indonesia 1996-2006. Parasitol Int 2007;140-143, 2007

[5] Wandra T, Sutisna P, Dharmawan NS, Margono SS, Sudewi R, Suroso T. High prevalence of Taenia saginata taeniasis and status of taenia solium cysticercosis in Bali, Indonesia, 20022004. Trans R Soc of Trop Med Hyg; 100:346-53, 2006

[6] Departemen Kesehatan RI. Pedoman Pengendalian Kecacingan. Jakarta : Departemen Kesehatan RI, 2015

[7] Dinas Kesehatan Kabupaten Gianyar. Laporan Tahunan Puskesmas Sukawati 1. Bali : Gianyar, 2015

[8] Ito A, Wandra T, , Swastika K, Li T, Dekumyoy P, Kosolsuk T, et al. 2014. The Present Situation of Human Taeniasis and Cysticercosis in Asia. Taeniasis/Cysticercosis and Other Parasitic Infections International Seminar. Bali : Denpasar, 2014

[9] Margono SS, Wandra T, Swasono MS. Taeniasis/cysticercosis in Papua (Irian jaya), Indonesia. Parasitol. Int ;55:S143-8. 2006 
[10] Salim L, Ang A, Handali S, Tsang VCW. Seroepidemiologic Survey of CysticercosisTaeniasis in Four Central Highland Districts of Papua, Indonesia. Am. J. Trop. Med. Hyg., 80(3), pp. 384-388, 2009

[11] Sah, RB, Paudel IS, Poudel P, Baral R, Jha N, Pokharel PK. A study of Prevalence of Taenia Infestation and associated Risk Factors among the School Children of Itahari Municipality, Eastern Region of Nepal. J Environ Occup Sci, 2 (3), 149-154, 2013

[12] Wandra T, Margono SS, Gafar. Taeniasis/cysticercosis di Indonesia 1996-2006. Parasitol Int;140-143, 2007

[13] Wandra T, Margono SS, Gafar MS, Saragih JM, Sutisna P, Sudewi AA, Depary AA, Yulfi H, Darlan DM, Okamoto M, Sato MO, Sako Y, Nakao M, Nakaya K, Craig PS, Ito A. Current situation of taeniasis and cysticercosis in Indonesia. Trop Med Health 35: 323-328, 2007

[14] Wandra T, Sutisna P, Dharmawan NS, Margono SS, Sudewi R, Suroso T, et al. 2006a. High prevalence of Taenia saginata taeniasis and status of taenia solium cysticercosis in Bali, Indonesia, 2002-2004. Trans R Soc of Trop Med Hyg ;100:346-53, 2006

[15] Wandra T, Sudewi RAA, Sutisna P. 2006b. Taeniasis and cysticercosis in Bali and North Sumatra, Indonesia. Parasitol Int ;55:S155-60, 2006 